Paideusis

\title{
A Pragmatic Utopia? Utopianisms and Anti-utopianisms in the Critique of Educational Discourse
}

\section{Christopher Martin}

Volume 15, Number 2, 2006

URI: https://id.erudit.org/iderudit/1072679ar

DOI: https://doi.org/10.7202/1072679ar

See table of contents

Publisher(s)

Canadian Philosophy of Education Society

ISSN

0838-4517 (print)

1916-0348 (digital)

Explore this journal

Cite this article

Martin, C. (2006). A Pragmatic Utopia? Utopianisms and Anti-utopianisms in the Critique of Educational Discourse. Paideusis, 15(2), 37-50.

https://doi.org/10.7202/1072679ar
Article abstract

This paper seeks to address what I claim are competing utopian and anti-utopian impulses within educational discourse aimed at formulating a just and fair conception of public education. On the one hand, there is a tendency to prescribe concrete utopias - normative blueprints that claim to portent how a redeemed public education will (and ought to) be. On the other hand, there is the tendency to prescribe material revolutions - strategic blueprints that dictate the kinds of political action that educators must undertake in order to bring about lasting social change. I argue that both of these approaches to formulating a just conception of public education are flawed for pragmatic as well as normative reasons. As a way of avoiding the pitfalls inherent to utopianism and anti-utopianism, I suggest that those of us interested in a just conception of education maintain our focus on a kind of pragmatic utopianism. While pragmatic utopianism requires that we abandon the notion that we can ever know what a redeemed public education will look like in its particulars, it does set out standards of deliberation that can increase the likelihood that we will be able to address issues of educational justice as they arise.
This document is protected by copyright law. Use of the services of Erudit (including reproduction) is subject to its terms and conditions, which can be viewed online.

https://apropos.erudit.org/en/users/policy-on-use/ 
Paideusis, Volume 15 (2006), No. 2, pp. 37-50

\title{
A Pragmatic Utopia? Utopianisms and Anti- Utopianisms in the Critique of Educational Discourse
}

\author{
CHRIS MARTIN \\ Memorial University of Newfoundland, Canada
}

\begin{abstract}
This paper addresses what I claim are competing utopian and anti-utopian impulses within educational discourse aimed at formulating a just and fair conception of public education. On the one hand, there is a tendency to prescribe concrete utopias — normative blueprints that claim to portent how a redeemed public education will (and ought to) be. On the other hand, there is the tendency to prescribe material revolutions - strategic blueprints that dictate the kinds of political action that educators must undertake in order to bring about lasting social change. I argue that both of these approaches to formulating a just conception of public education are flawed for pragmatic as well as normative reasons. As a way of avoiding the pitfalls inherent to utopianism and anti-utopianism, I suggest that those of us interested in a just conception of education maintain our focus on a kind of pragmatic utopianism. While pragmatic utopianism requires that we abandon the notion that we can ever know what a redeemed public education will look like in its particulars, it does set out standards of deliberation that can increase the likelihood that we will be able to address issues of educational justice as they arise.
\end{abstract}

\section{Concrete Utopias and Material Revolutions}

Karl Otto-Apel, whose contribution to a discourse theory of morality has been the target of criticism for its purportedly utopian sentiments, says: "It might...be the case that a rationally groundable ethics readily provides criteria for the demarcation between a dangerous and a necessary utopia." (1992, p. 24). On his view, such criteria are embedded within the very discursive practices by which we come to agree on how we might want to structure our communities. I agree with Apel. A cautionary approach to utopian sentiments is an appropriate one. I would characterize such an approach as one that does not necessarily dismiss or uncritically accept the neccessity for hope and possibility in our thinking about justice and society. Furthermore, I argue that a landmark for guiding a cautionary approach can be found in extant discursive practices. From the point of view of philosophy of education, a cautionary approach is particularly germane to political or radical critiques of educational discourse, critiques that traditionally seek to overturn the current state of public schooling with the redemptive vision of a more just system. It is the tracing of a cautionary approach to educational reform in the interest of a just public education that I would like to explore in this paper.

As Richard Rorty (1998) points out, intellectuals have had the misfortune of being caught up in the idea that they know, or somehow ought to know, something about the underlying (and esoteric)

(C) Copyright 2006. The author, Chris Martin, assigns to Paideusis the right of first publication and educational and non-profit institutions a non-exclusive license to use this document for personal use and in courses of instruction provided that the article is used in full and this copyright statement is reproduced. Any other usage is probibited without the express permission of the author. 
forces that determine the fate of human communities. As Rorty puts it, "Once we claimed to know that justice could not reign until kings became philosophers or philosophers kings; we claimed to know this on the basis of a searching inspection of the human soul. More recently, we claimed to know that it will not reign until capitalism is overthrown and culture decommodified; we claimed to know this on the basis of a grasp of the shape and movement of history" (p. 238). Often accompanying each prescription for a just society is a blueprint for an education designed to make sure that the objects of reform (the members of the human community) behaved according to the plans of their purported reformers. Examples of this range from Plato's educational state in The Republic ${ }^{1}$ to the critical pedagogy of Henry Giroux and Peter McLaren who take as a matter of principle answering Marx's question about who will educate the educators.

I argue that focusing on a discursive and procedural approach to educational reform can help us to get rid of the idea that we can know exactly what kind of place that public education must inhabit. I recommend that critics of educational discourse let go of the idea that they can hand over to school teachers a "normative blueprint" (Habermas, 1993, p. 176) that is to be earnestly followed. In other words, we should be on guard for what I view as a tendency in educational discourse to prescribe concrete utopias, that is, pre-given ends of what a just public education must be. At the same time, I also recommend that critics of educational discourse be equally cautious about the idea that they can formulate a "strategic blueprint" that dictates in detail the kind of political action that teachers interested in social justice need to undertake. In other words, we should be on guard for what I view as the tendency to design material revolutions, that is, some combination of political ambitions or strategic goals that will purportedly overturn all forms of oppression and inequality.

As a possible alternative, perhaps we would move much closer to the "just" education we claim we want if we promoted a change in our own self-understanding as educational theorists. The kind of movement I have in mind is from being sure of what public education ought to be, to being not at all sure about the particulars of a totally just arrangement of schooling, having an expertise that emboldens us to make modest proposals from the perspective of someone participating in the political process. This means forgetting altogether that we can validly project concrete utopias and material revolutions. Such intellectuals would always hold that educational policy and reform is "up to us", where this us refers to as truly a democratic and inclusive an educational community as possible. They would completely remove from their language any idiom that encourages the kind of distanced, Archimedean point of view on education that makes them say (usually unhelpful) things such as "educators need to do X" or "teachers need to challenge Y". In my view, teachers do not need us to prescribe blueprints for "radical change" of our schools. This does not mean that radical change is not necessary or is not possible; it just means that there is probably not much we can do in the role of educational theorist or critic to portent what this radical change will exactly entail or how to make that change happen.

At the same time, abandoning the prescriptive language of the philosopher king or the imperative language of the revolutionary does not mean we give up trying to work with teachers as fellow participants in the hope of creating a better educational community. Philosophers of education concerned with questions of justice in educational discourse have much in their expertise and training to offer. I suggest that one such way would be for us to adopt a clarifying role; helping to identify those conditions whereby the participants themselves can best decide questions of educational justice and solidarity. Through the clarifying role of the educational philosopher, a critical approach to education discourse is adopted that pays careful mind to the kinds of criteria that helps us to navigate a path between the pathologies of a dogmatic utopianism on the one hand and a defeatist and cynical antiutopianism on the other. However, before saying something about the nature of this clarifying role, I want to discuss some of the unavoidable complications facing the extreme utopianism and antiutopianism threatening educational discourse today.

\footnotetext{
${ }^{1}$ See Gadamer, 1983.
} 


\section{The Critique of Utopian Reason: Redemptive Speculation Concerning Our Children's Futures}

On the one hand, educational theory and philosophy should be on guard for a potentially extreme utopian approach to educational reform. Such an approach aims to construct "concrete utopias" that ostensibly prescribe a blueprint of what a redeemed public education ought to look like. More specifically, I argue that a utopian approach that assigns a clear and distinct model of reform can present certain moral and pragmatic difficulties.

When criticizing "concrete utopias" in educational discourse, I am mainly concerned with the kinds of theoretical projects that I have alluded to earlier: what I see as largely attempts at social engineering, be they of a Platonist, Marxist, or Liberal variety. While people do not explicitly formulate a social plan for education in quite the same way that Plato did in The Republic, I think that certain critics of education may have inherited from Plato a way of speaking about education that continues to this day, a way of speaking that has become increasingly problematic as we move further into a modernity concerned with issues of pluralism, multiculturalism and a justice that does not account for itself in terms of a particular tradition or form of life. It seems to me that contemporary examples of this way of speaking about education can not only be found in E.D. Hirsh's oft-reviled Dictionary of Cultural Literacy, but in Aronowitz, Stanley and Giroux's critical response to Hirsh in their essay "Schooling, Culture, and Literacy in the Age of Broken Dreams." For those unfamiliar with either work, you will find in each the common conviction that what a just and fair education ought to be is essentially pre-given, consisting in an appeal to a kind of transcendent truth about justice and education that awaits universal recognition. What Rorty calls the "underlying force" that these works appeal to can be found, in Hirsh's work, within the strong, univocal voice of the American tradition. For his critics Giroux and Aronowitz, that same force can be found in a romantic politics of the culture industry going back to their intellectual heroes Adorno and Horkheimer. Both camps, their ideological differences notwithstanding, issue rejoinders concerning what these would-be reformers feel that educators "must do" in the form of a rescuing critique (or in the case of Hirsh, a revitalizing one) of public education from decades of inequality, injustice and imprudent governance.

In this sense, both the "Left" and "Right" in educational discourse are struggling to resist what David Halpin (2003) calls "narratives of decline" in education. Narratives of decline are those stories we tell each other about the failure of public education as a moral endeavor. Examples of these narratives include stories about how students do not value the same things now as they did back in the good old days (for the Right) or how capitalist society has oppressed our teachers (for the Left).

It only makes sense that in response to these kinds of stories we would find other, more hopeful stories to tell. This is what I think makes utopian fictions so effective and inspiring to the imagination. These "narratives of redemption", often culled from the writings of Marx, Plato or Adam Smith, appeal to those "underlying forces" that theorists and philosophers of a variety of political stripes use to create their own redemptive vision for the future of public education in crisis.

Some of these narratives can be a valuable source of inspiration for change. However, my concern is that they can evolve from therapeutic fictions about the kinds of places we would like to inhabit to assertions about the truth of a philosophical-historical transcendence that will happen only when we "get things right". In this sense, I share Richard Rorty's anti-realism, mainly with respect to the nature of substantive claims about justice and morality. Moral "oughts" have no independent existence in the world outside of our intersubjective selves. Realism would say otherwise-a position that must be avoided. Why avoid moral realism? Because when we do start to hand over questions of justice to metaphysics or world historical teleologies, rational discourse among participants concerned with the co-operative, dialogical justification of norms becomes split from the greater community and handed over to an "esoteric" philosophical ethics reserved for those who best understand those underlying forces necessary for transcendence. Moral realists, in my view, end up getting caught up in 
noble lies about who has gold in their souls, silly debates about who happens to be less bourgeois, or the passive idolatry of an invisible hand.

More disconcerting is that what appears to be a kind of speculative redemption in educational discourse could end up shifting what Apel (1992) calls the subject-object dialectic from that of "man over nature" to man over man. His claim is that one of the pathologies of utopianism is that we persuade ourselves that the kind of law-governed approach we bring to the scientific study of nature can be directly applied to the perfection of human society. Once we have the concept of an ideal end, the only thing in our way of achieving it is developing the technology (social, industrial, educational) necessary to make it happen. This paradoxical "social technics", which analyzes society in the interests of discovering a law-like prognosis about human behaviour, thinks that it can usher us into a realm of free subjects by treating us as fixed objects. Similarly, utopian-style educational reform, reform that begins with a concrete and material idea of what an emancipated public system ought to be, quickly devolves into heuristic, strategic actions undertaken in order to usher our ideal learning community into an actual one. Such strategies, if they were ever to be implemented, would inevitably rely on the reprogramming and reeducation of the "fixed object" that is the educational worker so that (s)he will behave according to our predictions.

When intellectuals begin speaking about "making" people aware of the "real" political and moral truths of which the rest of us are foolishly ignorant (and which they, of course, ascertain completely), or when they make categorical statements about how the ignorant masses need to be 'modified', it seems like a good time to enter into what Jürgen Habermas calls discourse-a form of communicative action premised on the idea that we as speakers and hearers of a language can expect others to make good on their claim that something is true or right. Communicative action is based on a theory of reason that argues that rationality is best understood in terms of the justifiability and criticizability of various claims in discourse. Communicative action happens when this form of reason is adopted speech oriented toward reaching understanding (Habermas, 1998). Perhaps one discursive action we could take is to ask the question: "What is it about your particular vision of a utopia that makes you so sure that your vision is the only way we could come to a just society? Why should we agree with you?" Discursive action seems like a good way to politely remind our esoteric, would-be reformers that our being has a prominent subjective component with thoughts, feelings, ideas and notions of reform of our own. Unless, of course, we do not have the required amount of gold in our souls (or too much bourgeoisie in our blood), in which case we supposedly could never understand their answers to begin with. This approach to moral truth and justice is a product of utopian reason taken to its logical conclusion. For once the critic's redemptive speculations about a just public education crystallize into a material and substantive conception, the implementation of a normative blueprint designed to usher in the perfect community begins to take precedence over and above dialogue about shared goals and interests-once someone knows exactly what the rest of us really need, why waste time talking about it?

There is a pragmatic component to the unfeasibility of utopian reason as well. For even if we could "get public education right" in theory, it is unlikely that critics of educational discourse would get very far with their particular conception in practice. Robert K. Merton ably demonstrated this in his work on self-fulfilling and self-defeating prophecies. Merton's essential point is that when we try to predict or prophesize the future, the prediction becomes a part of the situation itself, changing and undermining the very prediction being made. ${ }^{2}$ A good example of this might be the stock market, where predictions on stock prices actually change the value of the stock being predicted. An even better example might be the reaction of voters to predictions about their choices at the polls. The rise of the "strategic" vote seems to be a consequence of polling predictions being incorporated into the voter's decision-making process. Utopian critics of education, prognosticating the way education 'ought' to be on the basis of a quasi-scientific view of human behavior or essentialist claims about human nature,

2 "Public definitions of a situation (prophecies or predictions) become an integral part of the situation and thus affect subsequent development." (Merton, 1967, p. 423). 
face the same unpredictability. ${ }^{3}$ While they define the situation in one way, teachers and students will react in their own way to issues of injustice and inequality, changing that situation. Apel describes this phenomena as Merton-effects: "Human beings are... at least the subjects of their own actions to the extent that their reaction to prognoses-known to them! - of their behaviour cannot be predicted" (1992, pp. 28-29). Intellectuals cannot reasonably expect teachers and other stakeholders to sit idly by as we make wishful projections concerning how they ought to act in a particular historical moment, an historical moment that is bound to change as the "objects" of prediction begin to develop their own self-understanding of the situation. For the utopian reformer, the practical solution is to act in such a way that these pesky "Merton-effects" are eliminated or, at best, suppressed. Just as the financial world creates laws about information concerning stocks in order to regulate the behaviour of the market, the utopian critic of education would have to make sure any information about a plan for the social engineering of schooling were kept secret from those being affected because a public prediction would change the situation upon which the prediction was based. The moral and political implications of a type of reform that can only work by preventing people from reflecting and acting on their evolving self-understanding is hardly in keeping with public reason.

The difficulty of creating the kind of "concrete" utopia that some critics of public education are talking about is well described by Thomas Green, in his book Voices (1999), which is primarily concerned with decidedly non-prescriptive moral education:

Even in a benign setting like that described in Skinner's Walden II, it is practically certain that someone will tinker with the thermostat in the nursery just for the fun of it and everything, in consequence, will be changed. In Paul Tillich's world where people have 'the courage to be', it is practically certain that some will find attraction, if not fulfillment, in 'the courage not to be'. Social perfection, planned for and educated for, is hard to come by except through suppression, censorship, or violence of some kind. (p. 11)

Our belief is that the kinds of theories of political action and transformative change that philosophers and critical theorists of education share amongst each other will work only when teachers act on them. But as long as teachers have their own ideas about social change there will be no utopian 'social technics of justice' for public education. We can see the folly of 'social technics' by looking at the kinds of challenges school boards face when they try to engineer their programmes of education undemocratically. The recent failed attempt to by a school board to suspend two teachers in Newfoundland's public education system for speaking out about working conditions is a good example of this. The school board's Skinnerian strategy of modifying the public behavior of professional teachers by punishing them had the unintended consequence of increasing public support for teacher's speaking out in the public sphere. The interpretation of the situation by parents, government, and the media demonstrated that people are socialized into intuitions about domination and oppression and that they will act against them given the right circumstances. We do not need to tell educators and the larger educational community how to feel and act when there is an injustice going on (though as fellow citizens we might want to give reasons why we think they should recognize a situation as unjust and act on that injustice in certain ways - but these reasons would rest upon theories of justice that may not be accepted by everyone and therefore part of the argument about a purported injustice also means debating these theories as well).

It seems reasonable to assume that educators will react just as strongly whether the 'social technics' are coming from technocratic administrators or educational theorists. Therefore, if we ever overcome the paradox of the Republic and philosophers of education became school principals or if

\footnotetext{
${ }^{3}$ Nicholas Smith (2005) explains the coding of human nature in scientific/essentialist terms as an attempt to rationally ground social hope. Smith identifies two categories of grounding: i) the assumption of natural human capacities and ii) the assumption of a providential order.
} 
school principals became philosophers of education, I hope that each would respond in kind to questions about what a redeemed public education would look like: "We are not quite sure what it would look like. We might have some ideas that we would be willing to share, but ideally, we think we need to discuss them with everyone else in the community first."

\section{The Critique of Anti-Utopian Reason: Limits of Political Realism in the Critique of Schooling}

I propose (but do not prescribe) that intellectuals who critique the justice of public school practices and policies might be interested in avoiding various kinds of prescriptivism from their language games. It makes no sense, either ethically or pragmatically, in my view, to have one group talking about what education ought to be and the other group implementing it. So instead of saying things like: "teachers are victims of ideology x", "teachers must do y" or worse, "teachers are naïve for believing z", I propose that we replace these ways of speaking with things like: "I suggest that we might be interested in doing A for reasons $\mathrm{x}, \mathrm{y}$ and $\mathrm{z}$ " or "I propose that those of us concerned with education reconsider 'p' and here's why... what do you think?". And while many intellectuals probably do this implicitly (I am thinking of the presuppositions of argumentation in Habermas's sense ${ }^{4}$ ) it would make sense to be more explicit in their language about it if they want these suggestions to be taken seriously.

So much for a radical utopian perspective. But what about a view from the opposite end? What about a view that would have us believe that creative visions about a redeemed public education are far too ephemeral? From this angle, normative ideas have no force and little pragmatic value to make their discussion worthwhile. Such a stance suggests that education will never escape the original sin of oppression and power. Better to focus on constructing a strategy of real change, of the creation of a blueprint for a material revolution that eschews dialogue for action.

I argue that equally as disastrous as the moral realism of concrete utopianism is exactly this kind of strong political realism or anti-utopianism. It would be right to be more cautious about how we talk about educational reform and enthusiastic about overturning appeals to "underlying forces". At the same time, we need to be equally cautious about subscribing to the idea that we have nothing useful to say at all. We should not forget that educational theorists are also citizens who happen to have a valuable skill-set, citizens that are participating in discourse about educational reform. As fellow participants within the larger educational community, we rely on communication with others to advance and share our views. This means resisting the temptation to think that making good on an interest in a just public education system should be left to those who are willing to engage in strategic power politics or that teachers must be left to struggle by themselves. I see this kind of pessimism from fellow colleagues when they say things like: "Since when did ethics ever make anyone be just and good, anyways!" The pessimism entailed in this statement is made obvious by the unstated assumption that norms need to compel people to act for those norms to be valid. Paulo Friere argues that cynicism that people can do good things of their own will is a strong mark of authoritarianism (1999).

People often look to cases of corruption, authoritarianism and other unpleasant things to argue that the hope that we can make good on our intuitions about justice is naïve. However, the danger of relying on what is the case as a limitation on what we ought to do or a limit to what is possible does more than commit a naturalistic fallacy. It closes us off from getting a better insight into what exactly is this 'is' that we claim to be burdened by. Focusing exclusively on the fact that from a sociological point of view there are frequently distortions of relations of communication (such as occurs in certain types

\footnotetext{
4 Habermas claims that procedures of scientific and moral inquiry comprise a particular formalization of counterfactually presupposed communication free from strategic actions, a presupposition made by anyone involved in argument or discourse in general. For a very different reading of how scientific communities function, see Bourdieu, 2000.
} 
of media) as a sufficient justification for opting out of discourse, for example, can close us off from the reciprocal communicative moment experienced from the perspective of people in every sincere attempt to understand one another. Reciprocity as a necessary condition for mutual understanding is an important 'is' that the political realist overlooks. He might reply by saying that reciprocity rarely ever bears its promise and he has the empirical data to prove it. Yet it is reciprocity (even if it is thwarted in particular instances such as when our assumption that an interlocutor can explain why he disagrees with our claim is mistaken) that makes it possible for the "realist" to question the very legitimacy of discourse as a means for addressing injustice. Attempts at communication can often be confusing, unclear and unfulfilled. That something is fallible, however, does not mean it is faulty. If this were the case, we would have to say that our trust in a doctor or teacher is always an irrational trust. From a pragmatic point of view, we have to put these doubts about teachers and doctors aside if we want to go about the business of staying healthy or getting an education. So, just as we can ask questions of reformers that seek to tell us what to do, we can also use discursive action to ask questions of political realists who claim that we cannot have things any other way. In this case, the fact of discursive action can remind the anti-utopian that we are more than rational choosers seeking to maximize our selfinterests and that we can indeed suspend our prejudices in the interest of mutual understanding. The fact that the political realist would choose to argue this very point suggests that he tacitly agrees: his choice to argue through the reciprocal transaction of reasons, as opposed to using violence or rhetoric, attests to this.

Anti-utopianists are involved in a struggle similar to the utopianists. While the utopianist is trying to will himself into a redemptive trajectory far and away from narratives of decline, anti-utopianists are so caught up in narratives of decline that they seem to have forgotten a language of social hope and redemptive possibility. Where does this amnesia come from? I am sure there are many causes, I can suggest one that might be particularly influential and direct us to the underlying problem. Injustice makes us angry. It motivates us to ask good questions about the status quo. We wonder why things are the way they are and not some other, better way. In asking these questions, we sometimes adopt the position of a distanced observer of the historical trends shaping our era: industrialization, the growth of capitalism, the rise in pollution and the increasing anarchism of much of contemporary foreign policy. Such a genealogy can leave us thinking that things cannot be any other way. We might see fate where we should see changeable (but often tenaciously resilient) trends. Apel (1992) describes the historical frame of the anti-utopian observer as follows:

The quasi-automatic and system-immanent progress of modern industrial society is today in fact taken to be the realm of possibility; and accordingly, any person is taken to be utopian who... believes it to be possible to break out of the general direction of things, in order perhaps to express through public discourse possible goals that are not pregiven as self-evident goals by the industrialization process. (p. 34)

Apel's point makes clear the underlying cause of the anti-utopianist's inability to speak earnestly about hope and possibility: a restricted view of the "realm of possibility" that is a consequence of his self-exclusion from public discourse. Let me explain. If we reconstruct history as the succession of one regime of power after another, the only way we can think about changing history is through an appeal to that same power. As a result, a political realism sets into our way of thinking that seals us off from the perspective of people that have potential to deliberate about how we might want to make things different and come to some kind of unforced agreement. The political realist adds the question: "Why discourse?" to "Why be moral?" ${ }^{5}$. Meaningful hope and possibility makes no sense from this point of view.

\footnotetext{
${ }^{5}$ Note that both questions are contradictions. To ask "Why discourse?" is a discursive act. To ask "Why be moral?", a question about one's obligations to others, is a moral question.
} 
It is at this point that we arrive at a common problem for both utopian and anti-utopian ways of speaking and reasoning about reform in public education. Both involve exile from public discourse. In the case of the utopians, it is the teachers and the larger community that are supposed to be exiled. Here, intellectuals are expected to do all the discoursing (setting goals and positing ends) while nonexperts and teacher-practitioners serve as targets of policies and re-education (i.e. objects) that need to be modified in order to ensure proper implementation. In the case of anti-utopians, on the other hand, intellectuals attempt a kind of self-imposed exile from public discourse. These deposed philosopher kings watch the power politics of the world with an "understanding" that only force and vulgar (instrumentalist) pragmatism make change - and it is unlikely, they would say with resignation, that such change will be for the better. It would be no surprise that from this perspective, generating languages of hope and possibility would be a difficult thing to do.

In response to the pessimistic language games of the anti-utopian, Henry Giroux, reading Ernst Bloch, recommends that educational theory provide resources for the development of a "utopian logic as part of a project of possibility" (2005, p. 32). While I have already expressed reservation about speaking about things such as a pre-given "logic" of utopia for reasons already given, what I think Giroux is trying to say and that is worth holding on to is that we need to speak about educational reform in a way that does not close us off to what Apel calls "the public discourse of possible goals." We often take a distanced and objective stance on educational discourse and we have good reasons for doing so. A sociological perspective on public education is and will continue to provide important insights about how schooling functions. It certainly can make us aware of our own practices. I remember reading that the average time a teacher waits after asking a question is around three seconds. These are useful insights that we would be less likely to discover by relying on a strictly subjective take on our own practices. However, what I think Apel might add to this is that whenever we discover new things about how, for example, domination, power-relations, strategic action, or political rationality works in our educational institutions, we need to return to discourse and consult with others about how we understand and potentially respond to these findings. The understanding and subsequent response to these explanations concerning how schools function depends on the community being affected by them, a community that philosophers of education necessarily include themselves in. To continue the example, if, as a community we agreed that asking questions and not waiting for answers was an unconscious but illegitimate expression of power in schooling somehow, we can then make decisions about how we want to change our own ways of teaching. Note that this is different from the current approach of many school boards, which is to "target" teachers for retraining without involving them in significant debate or reflection. The limits of political realism is demonstrated in the fact that political actions unavoidably presuppose goals, goals that only have meaning within communities that propose, consult and agree (or disagree) on them no matter how exclusionary or esoteric that community might happen to be. The "political" issue then is really about how we can communicate in just and fair ways when we seek to come to an understanding and, ideally, agreement concerning these goals.

We can make a similar case concerning theories of power in schooling. Imagine being a professional teacher in our schools today and reading some of the Foucault scholarship that is being produced in educational theory. These comprehensive and often insightful studies concerning the operation of power in the school can offer, to a degree, a certain healthy skepticism about the innocence of teacher practice and school administration. As Henry Giroux insists, "teachers' work needs to be analyzed in terms of its social and political function within particular regimes of truth" (2005, p. 212). But I am often left wondering how "innocent" teachers really see their practice in the first place. Do we really need to tell them that they are often left in a position of having to determine, as Foucault would say, the least harmful configuration of power relations? Such a position is endemic in our under-funded education systems. I can imagine a public school teacher reading Foucault scholarship having a different take on things. Rather than "resisting relations of domination" that derive from the "decentralization of govermentality and networked power" via a "cultural politics", rather than losing sleep over the intrusion of the "panoptic society" into the school via computers, the 
teacher might bring a different list of concerns. S/he might suggest that instead, we need more computers. S/he might point out that a more expedient "resistance" to the violence creeping into our classroom would be best addressed by convincing state governments to hire more teachers, limiting the number of children we cram into one classroom and making schools look more like playgrounds than prisons. S/ he might suggest that putting more money into schools would do more for making teaching more resistant to domination than a truckload of Foucault scholarship. In fact, I would suggest that many of us would agree with him: most of us would rather have our children go to a well-funded public school where the teachers have not read a line of Foucault rather than an under-funded one where the teachers all had a copy of Discipline and Punish on their desks. Furthermore, we have reason to think that Foucault would agree with us. ${ }^{6}$ This doesn't mean that a "grassroots" or "common sense" view of the public education is necessarily superior. That would be crass anti-intellectualism. Foucault offers important resources about how to best proceed when we agree that we need to undertake strategic, political actions. However, my argument does suggest that we need to find out, though discourse, how things like a critic's imperative of "resisting relations of domination" might translate into the teacher's demand that "we need more funding." " We could spend more time, I think, in working on creating a mutual understanding between the different languages of critique that exist between critics of education and professional teachers. It would enrich Foucault scholarship just as much as it would enrich teacher practice. It would also aid open, democratic deliberation of educational change and reform.

Therefore, I would submit that educational critics should shift their emphasis on a meeting of languages between intellectuals, professional teachers, school councils and students. The effort to reach mutual understanding between stakeholders interested in justice would serve as an experiment in a nonprescriptive political education - a political education that focuses on a capacity to be political rather than subscribe to a particular politics. Rather than try to diagnose the ills of education systems on the basis of a particular theory of oppression or alienation, a deliberative, shared political education would provide mutual benefits to all concerned with getting to some acceptable and generalizable conception of justice and fairness in our educational institutions. Educational critics would learn the language of teachers and students struggling with inequality in the schools, while teachers would learn the language of critical social theory. As the philosopher Richard Pring puts it, "to engage in intelligent reflection and discussion, one needs to acquire the languages which are relevant...in acquiring such concepts, one is not thereby acquiring a set of political beliefs, but rather a capacity to examine them and to accept or reject them in light of relevant reasons" (2004, p. 134). Pring endorses political education in public schools as education in political understanding, a decidedly open and undogmatic one. ${ }^{8}$ In terms of our concerns, Pring's account of political education suggests that educational theorists acquiring the

\footnotetext{
${ }^{6}$ I believe that at the least, Foucault scholarship in education, if it is serious about alleviating oppression in school, should shift to detailed empirical studies about power-relations in the school as opposed to speculation concerning how they might work. As Foucault himself said, in a discussion about educational institutions, no less, when identifying relations of domination one should "be both extremely prudent and extremely empirical" (Foucault, 1984, p. 378). I take "prudent" to mean "no offhand generalizations" and "empirical" to mean "go on out there and do field research".

7 To those who might say that a well-funded school does not necessarily solve the problem of oppression and authoritarianism I would reply that teachers as a group are already pretty well socialized into democratic sentiments and that the proper resources invested into education would allow for a fuller expression of the sentiment.

${ }^{8}$ Pring makes an important distinction between the political understanding of education and the understanding of political education. Political understanding of education views the function of education from the perspective of competing political interests - education is way of promoting particular political agendas in the public sphere. Understanding of political education sees public education as having some degree of authority and autonomy from existing political structures and works to foster an understanding of the political. Pring's political education focuses on political understanding, an education that must be open to various political ideas and can develop skills and capacities for political deliberation lest it be accused of regressing into a particular political understanding of education.
} 
political language of the teachers and students can better understand the "real" politics of schooling, just as acquiring the political language of critical social theory can help students and professional teachers better understand the "cultural" politics of theory.

As participants in public discourse who have an abiding interest in the formulation and outcome of goals, reforms, and problems, intellectuals can offer their expertise, but not in the manner of political experts that bequeath strategic blueprints to educators. Rorty (1998) presents a useful account of why intellectuals should think about letting go of the attempt or idea of being political strategists:

Lately we have been concentrating on cultural politics and trying to persuade ourselves that cultural, and especially academic, politics are continuous with real politics. We have been trying to believe that upsetting our students' parents will sooner or later upset unjust institutions. (p. 238)

However, Rorty asserts that we really have no idea how to construct a general theory of oppression that will overturn injustice. Realizing this will mean

Giving up the claim that philosophic or literary sophistication is important because it prepares us for the crucial, socially indispensable role that history has allotted to us- the role of "critic of ideology.” (p. 240)

In Rorty's account we see the portrait of the philosopher king fantasizing about being a field marshal, dishing out political battle plans, all the while forgetting that his ways of speaking and of understanding warfare (cultural politics) has no unmediated application for his troops involved in real battles. Rorty would prefer that we acknowledge that we have no idea what the future of human societies ought to hold. Inverting Smith's (2005) observation that acknowledging that one merely hopes is to concede that one does not really know, Rorty wants to insist that one does not know as a way of admitting of hope. To Rorty's account I would only add two things. First, the abdication of the role of "critic of ideology" should, with respect to educational theory, include the abdication of the "critic of power". Second, that rather than dismiss the role of the educational theorist as social critic, we experiment with the adoption of a somewhat more limited, deflated role.

As a positive alternative, the anti-utopian critics could try a shift in emphasis from that of a political realist to that of a political educator (in the tradition of Pring's notion of political education as an education in political understanding). S/he can, for example, use her knowledge of the political to help clarify necessary communicative conditions under which participants deliberating about educational issues can come to the best decision among a variety of competing interests. Here we would understand "best decision" to mean one that could be warranted as acceptable by as many concerned as is possible, an inclusiveness that prevents the exile of individuals from public discourse. One such "discursive condition" that the political educator would excel at would be fostering a capacity to examine the political beliefs of oneself and of others in light of relevant reasons. This does not mean converting politically minded intellectuals into "discursive" technicians. What it does mean is that intellectuals are better viewed as politically minded citizens whose interest in the political can translate into, in the role of intellectual, an interest in better communication about political understanding.

This alternative, deflated role of the critic of injustice in public education is better placed to situate social hope for public education. It might mean that theorists have to be satisfied with never entirely getting rid of injustice (though they would always strive for improvement) and it might mean that they have to be satisfied with being persistent and dedicated reformers rather than nostalgic "radicals". The attempt to fuse operative ideals9 of universal, public communication with the political

\footnotetext{
9 Jürgen Habermas calls those ideals we hold concerning the sincerity of others when we engage in
} communicative action for purposes of mutual understanding “idealizing presuppositions". 
realities of the particular context within which teachers and other educators are working opens up a different kind of utopia for critics of educational discourse with an eye to justice to aim for: pragmatic utopianism. I would like to suggest that pragmatic utopianism brings together the best things about the ideals of the utopian critic and the political savvy of anti-utopian critic, the reasons for which I will outline below.

\section{Pragmatic Utopianism: Norms of Communication as a Landmark for a Cautious Utopian Spirit in the Critique of Public Education}

I have been suggesting a dual-role for philosophers of education and other critics interested in a just and fair conception of public schooling. On the one hand, they can make modest proposals about what a just education might look like. However, these proposals should always be made as a member of an educational community whose stake in the outcome is as legitimate (but no more legitimate) than any other. This means endeavoring to purge appeals to transcendent "underlying forces" or the implied exclusions of others from critical discourse. On the other hand, we can exploit our literary and philosophical expertise as facilitators of communication between different points of view on substantive issues of justice in public education. This means abdicating the self-aggrandizing role of "radical theorist" and the idea that intellectuals can turn their cultural politics into operative political plans for revolutionary change in the schools.

The refutation of a priori political goals, the adoption of a language of possibility, an inclusive public discourse and the acknowledgment that we all have intuitions (however fallible) about justice and solidarity are nicely summarized in Pring's (2004) proposal for a critical, political discourse of education:

There is no more wisdom at the centre of politics than there is at the periphery, no more understanding in the Department of Education and Science of what is right or wrong than there is in the schools, no more authority in the political tradition of the government than there is in the education of the governed. (p. 139)

Therefore,

Political education requires...openness to alternatives and possibilities concerning what is worthwhile; it requires the skills and dispositions to engage in such deliberation; and it requires the context in which such openness, skills and dispositions might be nurtured. It requires, in other words, educational institutions which embody those very tentative understandings, that acceptance of uncertainty, those dispositions and values to which it is trying to introduce young people. Unless one can claim certainty about the precise aims of education, then those aims must themselves be subject to perennial and critical discussion. Without certainties [we need] the democratization of the process of problem-solving. (p. 139)

Is Pring himself doing what we have been saying that philosophers of education should avoid doing and imposing ways of acting and conducting educational reform? I think not. It is important to note that what Pring is arguing for is the recognition of a universal public discourse to which everyone belongs, with everyone making a contribution and therefore, with nothing being decided upon in advance. A critique of utopian and anti-utopian reason reveals the limits of reformist arguments, limits that Pring's vision does not breach. Participants making critical arguments that implicitly or explicitly exclude themselves or others from discourse are engaged in a contradiction. We cannot rationally argue without presupposing discourse (i.e. without assuming that there are other participants who will agree or disagree with us) and we cannot discourse for justice unless all are included (even if human finitude prevents literally everyone from participating at every moment, all are included in principle as potential 
members of public discourse). In my view, Pring's identification of the neccessity for the "democratization of the process of problem-solving" in a world where we will never have final certainty or "ultimate justification" about the aims and ends of education expresses a generalizable normative moment embedded in argumentation concerning educational justice. I want to formulate this normative moment in terms of what I call a pragmatic (or cautious) utopianism in educational discourse. Pragmatic utopianism is an approach to critique in the interests of justice that maintains a landmark for navigating a cautious approach to educational reform between utopia and anti-utopia.

Pragmatic utopianism combines the pragmatic concern that we will always be trying to solve problems getting in the way of an actualization of a utopian (just and fair) education system with the normative claim that morally legitimate and prudentially effective solutions can only realistically happen when deliberation regarding these problems are open to all concerned. The pragmatic concern acknowledges that what we define as a problem and what we recognize as a solution will always be changing as the historical, economic and social circumstances change and that those affected by these changes are, in turn, involved in a constant process of learning and understanding. The normative concern acknowledges that public discourse about these problems and solutions assumes reciprocity and symmetry between participants, the ability to account for the reasons behind claims to truth, and the inclusion of all concerned-what Apel and Habermas call "idealizing presuppositions of argumentation". Our normative concerns and our pragmatic concerns dovetail when we try to construct a just public education.

We have already seen that making decisions designed to promote justice and solidarity in education necessarily requires, for pragmatic as well as moral reasons, that everyone concerned be recognized as a participant in public discourse. Pragmatically speaking, programmatic exclusion creates unpredictable "Merton-effects" and undermines the effectiveness of our reforms. Morally, objectifying others and excluding them from discourse is contradictory-we exclude others while granting discourse to ourselves and yet we rely on the autonomy and dignity of others for our utterances to be recognized in discourse. Exclusion from discourse is morally and epistemically wrong; but as well, the prudential viability of a just system of education requires the participation of everyone. When we commit to social justice in education, normative concerns that could otherwise be ignored by utopian or anti-utopian reformers focused on concrete utopias or material revolutions, respectively, must be recognized, not only because of the binding nature of norms, but because they are also pragmatically presupposed in any dialogue that aims for agreement on goals aimed at reform in the interest of justice. Another way of saying this is that when we talk seriously about issues of justice in education or any other sphere of action we are already implicitly committed to procedures that are obligatory if we want a realistic chance of moving closer to the justice we seek. When we leave people out of the decision making process, or we try to persuade or influence them by misleading them, or when we refuse to take their reasons for disagreeing seriously, any agreement on any policy, any reform or any political goal will be short-lived at best, inspiring resentment at worse and morally impermissible in either case.

We could proceed with a pragmatic orientation to educational reform and ignore the normative moment that occurs every time a group comes to deliberate about just goals and solutions. We could maintain that discourse really is not that important and that we best focus on strategic action. Stop talking and start doing, they would say. There are obvious limits that shorten the time we have to debate an issue or formulate a plan. However, if we act in ignorance of discourse, we will likely run up against another set of limits, limits of the kind that I have outlined earlier in my discussion about "antiutopian" reason. If strategic action were the only solution, intellectuals would not have much to say or do about justice in the schools. And if they tried to say anything they would be tacitly endorsing a discursive approach they claim is not necessary. If they actually acted in contradiction to norms of universal discourse and imposed solutions, we would expect resistance to our plans. And if we were successful it would only be a matter of time before we were found out and the formerly "reified" masses began plotting out a counter-solution. 
We could proceed with a totally normative orientation to educational reform and ignore that people do indeed act strategically. We could lament the fact if only people did what they ought to do, everything in education would be nice and perfect. But since people do not always do what they ought to do, as the thinking would go, intellectuals should try to figure things out amongst themselves and reeducate everyone else in these ways of thinking and acting. However, we will likely run up against limitations I have outlined earlier in my discussion about "utopian" reason. We would likely fall back into the old habits of prescriptivism and pre-given ends. We would try to set up the kind of political education that tries to inculcate one set of political beliefs instead of fostering abilities to deliberate and assess a wide variety of beliefs and goals. In other words, we would try to use political education to get rid of politics. ${ }^{10}$

Pragmatic utopianism, on the other hand, maintains a cautious optimism that "the democratization of procedures of problem solving" will lead to the best decisions humanly possible for addressing issues of inequality and oppression in schooling. Furthermore, the norms that are embedded in deliberation concerning educational policy and reform stand as a good landmark for checking to see if we are straying too far into either anti-utopian or utopian ways of speaking. When we talk about substantive political goals as if they are pre-given or a priori, for example, we know we are moving too close to the utopian end of things. When we avoid discourse with other stakeholders in education, we know we are moving too closely to the anti-utopian.

Clearly, the image I sketch of "utopian" and "anti-utopian" perspectives represent particular lines of thought taken to their logical extremes as opposed to categorizing or labeling points of view consciously adopted and maintained by various participants in discourse. In addressing questions of justice and fairness we all have a tendency to weave back and forth between each pole. Furthermore, there already exist valuable points of contact between intellectuals, public school teachers and policy makers (teacher education programs are but one example of this). There also already exist well-justified moral principles and pragmatic concerns that ought to be attended to by anyone concerned with justice in education. However, extreme utopian and anti-utopian thinking present real dangers to achieving the kind of public education we want, for they threaten to undermine those very discursive procedures that are necessary for legitimate deliberation concerning questions of justice. Pragmatic utopianism, therefore, can best be understood as a rubric for refining our already-existing approaches to these questions. At the same time, it is certainly clear to me that we have some way to go toward an insitutionalization of a universal public discourse concerning educational justice. An examination of contemporary approaches to "teacher professional development" reveals but one example of serious moral shortcomings in our deliberations concerning education. The failure to capitalize on the valuable professional experience and knowledge held by career teachers might be an example of a more pragmatic issue. At the same time, what an institutionalized public discourse might look like in its particulars, again, is largely up to the participants concerned-but I could imagine it approaching something along the lines of a (well-funded) deliberative democracy.

Finally, I would like to suggest some roles for the pragmatic utopian educational critic, recapping suggestions made throughout this essay. First, we can help to clarify languages of critique from all spectrums of the educational community, helping different groups to understand each other's philosophical and political goals and beliefs. Sometimes this will mean using critical theory to help educators to sharpen, make explicit, or reflect upon their intuitive knowledge about education and justice. Second, intellectuals can help to identify and articulate those necessary conditions under which we can come to agreement about issues of justice in public education. They can, for example, clarify the norms embedded in egalitarian communication and translate them into procedures that could be

\footnotetext{
10 "Utopian thinking as a guide to policy, is faulty, however, not simply because it attends too little to what is feasible, but it attends not at all to politics...no well developed literary utopia has ever included an account of politics...the promise of Utopia lies first in how the conflict among goods is to be resolved, and secondly, in the unstated claim that that the equilibrium so established can be made to hold." (Green, 1999, p.180).
} 
adopted by the policy-making community. This means focusing on, among other things, procedural difficulties that might be unique to particular education communities. ${ }^{11}$ The assumption here is that as these procedures improve, our critiques of public education will be more comprehensive, making subsequent plans of action more sensitive to the pragmatic issues facing professional teachers working in schools while maintaining a focus on the importance of the rational justification of those plans within public discourse. In other words, I suggest that critics of educational discourse interested in social justice shift their resources to developing procedures of critique.

\section{References}

Apel, Karl-Otto (1992). Is the ethics of the ideal communication community a utopia? On the relationship between ethics, utopia, and the critique of utopia. In Seyla Benhabib and F. R. Dalimayr (Eds.), The communicative ethics controversy (pp. 23-59). Cambridge: MIT Press.

Bourdieu, Pierre (2000). Pascalian meditations. Stanford, CA: Stanford University Press.

Foucault, Michel (1984). Politics and ethics: An interview. In Michel Foucault, The Foucault reader (P. Rabinow, Ed.; pp. 373-380). New York: Pantheon Books.

Freire, Paulo (1999). Education and community involvement. In Manuel Castells et al., Critical education in the new information age (pp. 23-59). Lanham: Rowman and Littlefield.

Gadamer, Hans-Georg (1983). Plato's educational state. In Hans-Georg Gadamer, Dialogue and dialectic New Haven, CT: Yale University Press.

Grioux, Henry (2005). Schooling and the struggle for public life. Boulder: Paradigm.

Green, Thomas (1999). Voices: The educational formation of consciousness. Notre Dame: Notre Dame University Press.

Habermas, Jürgen (1993). Morality, society and ethics. In Jürgen Habermas, Justification and application (pp. 147-176). Cambridge: MIT Press.

Habermas, Jürgen (1998). Some further clarifications of the concept of communicative rationality. In Jürgen Habermas, On the pragmatics of communication (pp. 307-342). Cambridge: MIT Press.

Halpin, David (2003). Hope and education: The role of the utopian imagination. New York: RoutledgeFalmer.

Merton, Robert (1967). Social theory and social structure (rev. ed.). New York: The Free Press.

Pring, Richard (2004). Political education: Relevance of the humanities. In Richard Pring, Philosophy of education: Aims, theory, common sense and research (pp. 119-141). London: Continuum.

Rorty, Richard (1998). The end of Leninism. In Richard Rorty, Truth and progress: Philosophical papers (pp. 228-243). Cambridge: Cambridge University Press.

Smith, Nicholas (2005). Hope and critical theory. Critical Horizons, 6 (1), 45-61.

\section{About the Author}

Chris Martin has recently completed his Masters of Philosophy (Humanities) at Memorial University of Newfoundland and teaches at Lakecrest Independent School, St. John's, Newfoundland. Email: chris_m_martin@hotmail.com

11 What kind of procedures, for example, will make critical social theory more accessible (in both the conceptual and institutional sense) to students training to be teachers? 